\begin{tabular}{c} 
Efficient $\operatorname{Vol} 2$ (3) (2019): 562 -577 DOI: https://doi.org/10.15294/efficient.v2i3.35909 \\
$\begin{array}{c}\text { Indonesian Journal of Development Economics } \\
\text { https://journal.unnes.ac.id/sju/index.php/efficient }\end{array}$ \\
\hline
\end{tabular}

\title{
Analysis of Factors that Influence the Acceptance of PBB-P2 Tax
}

\author{
Novita Rahmawati ${ }^{1}$, Etty Soesilowati ${ }^{2}$ \\ Jurusan Ekonomi Pembangunan, Fakultas Ekonomi, Universitas Negeri Semarang \\ Permalink/DOI: https://doi.org/10.15294/efficient.v2i3.35909
}

Received: Juny 2019; Accepted: September 2019; Published: December 2019

\begin{abstract}
The purpose of this study was to determine the effect of minimum wages, economic growth, and industry on unemployment in West Java. Industrial variables act as moderator variables. The method of data analysis in this study uses Multiple Regression. The type of data used is secondary data obtained from Badan Pusat Statistik (BPS) in 2013-2015 with 26 districts / cities in West Java. The results showed that the minimum wage had a positive and significant effect, economic growth had a positive but not significant effect, and the industry had a positive and significant effect. Moderating variables make the influence of minimum wages and economic growth have a negative and significant effect. The addition of moderation variables is proven to strengthen the influence of independent variables on the dependent variable. Suggestion: 1) the government must continue to regulate appropriate regulations so that an increase in the number of industries can be accompanied by an increase in employment opportunities. Economic growth will be better if it is able to provide employment opportunities; 2 ) Increasing number of industries is better when accompanied by increased employment opportunities. The community is encouraged to improve their skills to meet the criteria needed by the industry.
\end{abstract}

Keywords: Taxpayer Compliance, Taxpayer Awareness, Accessibility, Tax Services, Tax Sanctions.

\begin{abstract}
Abstrak
Tujuan dari penelitian ini adalah untuk mengetahui pengaruh upah minimum, pertumbuhan ekonomi, dan industri terhadap pengangguran di Jawa Barat. Variabel industri bertindak sebagai variabel moderator. Metode analisis data dalam penelitian ini menggunakan Regresi Berganda. Jenis data yang digunakan adalah data sekunder yang diperoleh dari Badan Pusat Statistik (BPS) pada 2013-2015 dengan 26 kabupaten / kota di Jawa Barat. Hasil penelitian menunjukkan bahwa upah minimum memiliki efek positif dan signifikan, pertumbuhan ekonomi memiliki efek positif tetapi tidak signifikan, dan industri memiliki efek positif dan signifikan. Variabel moderat membuat pengaruh upah minimum dan pertumbuhan ekonomi berpengaruh negatif dan signifikan. Penambahan variabel moderasi terbukti memperkuat pengaruh variabel independen terhadap variabel dependen. Saran: 1) pemerintah harus terus mengatur peraturan yang tepat sehingga peningkatan jumlah industri dapat disertai dengan peningkatan kesempatan kerja. Pertumbuhan ekonomi akan lebih baik jika mampu memberikan kesempatan kerja; 2) Meningkatnya jumlah industri lebih baik jika disertai dengan peningkatan kesempatan kerja. Masyarakat didorong untuk meningkatkan keterampilan mereka untuk memenuhi kriteria yang dibutuhkan oleh industri.
\end{abstract}

Kata Kunci: Kepatuhan Wajib Pajak, Kesadaran Wajib Pajak, Aksesibilitas, Layanan Pajak, Sanksi Pajak

How to Cite: Rahmawati, N., \& Soesilowati, E. (2019). Analysis of Factors that Influence the Acceptance of PBBP2 Tax. Efficient: Indonesian Journal of Development Economics, 2(3), 562-577. https://doi.org/10.15294/efficient.v2i3.35909

(c) 2019 Semarang State University. All rights reserved

\footnotetext{
Alamat Korespondensi :

Alamat: Gedung L2 Lantai 2 FE Unnes

Kampus Sekaran, Gunungpati, Semarang, 50229

E-mail : efficientjournal@gmail.com
}

ISSN 2655-6197 


\section{INTRODUCTION}

The tax is one of the largest sources of state revenue, including the Rural and Urban Land and Building Tax (PBB-P2) according to (Sri, 2006) saying that, "Land and building tax is the tax imposed on land and buildings. To carry out fiscal policy and facilitate services to the public, Law Number 28 Year 2009 concerning regional taxes and local user fees is formed by the central government, Law Number 28 Year 2009 contains the transfer of tax PBB-P2 which was originally managed by the central government transferred to the local government, thus all authority regarding the targeting, collection and receipt of PBB-P2 tax is the full responsibility of the Regional Government.

According to the Karanganyar Regency Regulation Number 3 of 2012 concerning Land and Building Taxes for Rural and Urban: a) That the Rural and Urban Land and Building Tax is a source of Regional Revenue, therefore the Regional Government needs to intensify the collection of Land and Building Taxes in order to increase services to the community, financing development and implementation of Regional Government; b) Whereas with the enactment of Law Number 28 of 2009 concerning Regional Taxes and Regional Retribution, the Rural and Urban Land and Building Tax is one of the Taxes that is the authority of the Regency;

In this study the researchers chose Karanganyar Regency because according to the PBB-P2 tax revenue data in Karanganyar Regency from 2014 to 2018 or in other words during the last 5 years the realization of the $\mathrm{PBB}_{-} \mathrm{P}_{2}$ tax revenue in the Karanganyar district was still far from the target set. Target data and realization of $\mathrm{PBB}_{2} \mathrm{P}_{2}$ tax revenue in the
Karanganyar district can be seen in table 1 below.

Table 1. Target and Realization of Karanganyar Regency PBB-P2 Tax Revenue

\begin{tabular}{lll}
\hline Year & Target & Realization \\
\hline 2014 & 28.009 .637 .084 & 22.415 .833 .924 \\
2015 & 28.085 .506 .530 & 23.100 .421 .887 \\
2016 & 28.120 .799 .733 & 23.507 .658 .291 \\
2017 & 28.332 .292 .050 & 23.697 .862 .044 \\
2018 & 28.497 .144 .169 & 23.438 .800 .643 \\
\hline
\end{tabular}

Source: DPPKAD Karanganyar district

Based on target data and the realization of PBB-P2 tax revenue in Karanganyar Regency from 2014 to 2018 is still far from the target set, even decreased from Rp. 23,697,862,044 in 2017 to become Rp. 23,438,80o,643 in 2018 even though $\mathrm{PBB}-\mathrm{P}_{2}$ revenues in Karanganyar Regency are targeted to experience an increasing trend every year.

NJOP is the marketable price at the time a tax object (land and building) is sold, the intended tax object is land and buildings that are eligible for tax. There are several factors that determine NJOP:

(1) Factors that determine the magnitude of the determination of the Earth NJOP:
a. The location
b. Utilization
c. Allotment
d. Environmental conditions
2) Factors that determine the amount of NJOP Building determination:
a. Building material
b. Building engineering
c. The strategic position of a building
d. Environmental factor 
Among the other sub-districts in principal or target tax revenue of PBB-P2. Karanganyar Regency, Colomadu Subdistrict is the District with the lowest level of PBB-P2 tax revenue when viewed from the percentage of Below is data on the percentage of tax revenue $\mathrm{PBB}-\mathrm{P} 2$ to the principal provisions per subdistrict in Karanganyar. realization of $\mathrm{PBB}_{2} \mathrm{P}_{2}$ tax revenue on the

Tabel 2. Percentage of PBB-P2 Revenue per sub-district

\begin{tabular}{lcll}
\hline Sub-district & Percentage of Revenue & Sub-district & Percentage of Revenue \\
\hline Jatipuro & 99,99 & Tasikmadu & 80,60 \\
Jatiyoso & 99,82 & Jaten & 86,15 \\
Jumapolo & 99,92 & Colomadu & 69,47 \\
Jumantono & 99,85 & Gondangrejo & 81,62 \\
Matesih & 97,97 & Kebakkramat & 87,34 \\
Tawangmangu & 82,72 & Mojogedang & 98,91 \\
Ngargoyoso & 98,62 & Kerjo & 88,99 \\
Karangpandan & $\mathbf{7 4 , 2 1}$ & Jenawi & 99,66 \\
Karanganyar & 42,56 & Total & $\mathbf{8 2 , 2 5}$ \\
\hline
\end{tabular}

Source: DPPKAD Karanganyar district

Based on data on the realization of PBB$\mathrm{P}_{2}$ tax revenue in each sub-district in Karanganyar district, it can be seen that the sub-district with the lowest percentage of realization of PBB-P2 tax revenue is Colomadu sub-district at $69.47 \%$, the second is Karangpanadan sub-district at $74.21 \%$. third is Karanganyar sub-district at $77.75 \%$, the fourth is Tasikmadu sub-district at $80.60 \%$ and the fifth is Gondangrejo sub-district at $81.62 \%$. The higher the percentage of tax revenue can be said to be effective and efficient tax collection, applies also to the opposite the lower the percentage of tax revenue realization means that tax collection is increasingly ineffective and inefficient so that efforts need to be made so that tax revenue, especially $\mathrm{PBB}-\mathrm{P}_{2}$ tax in Karanganyar district can be optimal. This research was conducted in 5 districts in Karanganyar Regency, namely: Colomadu, Karangpandan, Karanganyar, Tasikmadu,
Gondangrejo, with consideration that the 5 districts have the lowest tax revenue percentage among other districts.

The following are the factors that affect taxpayer compliance to pay the tax that becomes his obligation. According to (Rina Oktiyani, 2016) taxpayers who have the awareness to pay taxes will have a positive effect on the compliance of a taxpayer to pay taxes. According to (Burton, 2010) states that the best way that can be used to regulate taxpayers to be obedient to pay taxes and fulfill their obligations is to provide penalties that are enforced on each taxpayer who do not comply with applicable tax regulations. According to (Todaro, 1983) states that most developing countries state income from low taxes due to tax services that are not or not optimal both in terms of infrastructure and tax administration actors lacking integrity, causing tax revenues not to the maximum. 
Accessibility is the degree of ease achieved by people, towards an object, service or environment. According to (Nayoan, 2016) states that separately the variable ease of paying taxes has an influence on taxpayer compliance in paying taxes.

Based on the formulation of the problems stated above, the researchers compiled the following research questions: 1) What factors influence the receipt of the Rural and Urban Land and Building Tax (PBB-P2) in Karanganyar regency not reaching the target?

The objectives of the study are as follows: 1) Analyzing the factors that affect the receipt of the Land and Building Tax on Rural and Urban Areas (PBB-P2) in Karanganyar Regency did not reach the target.

According to Malcolm Gillis which was restated by (Aris, 2014) tax reform is all fundamental changes in all aspects of taxation. The main objectives of tax reform are: the achievement of high levels of compliance, a high level of trust in tax administration and increased productivity of the taxation apparatus, among these three objectives the most important goal is the achievement of high levels of compliance. To achieve a high level of compliance there are 3 strategies that can be carried out, namely: 1) Creating a program that can increase taxpayer awareness and increase compliance voluntarily. 2) Improving tax services so that compliance increases. 3) Combating non-compliance with programs or activities that can combat this.

According to (Aulia, 2018) states that the place and method of tax payments will affect the level of tax revenue $\mathrm{PBB}-\mathrm{P}_{2}$, because the easy way and the place of tax payments that are easily accessible will provide convenience for taxpayers in paying taxes, therefore it is best for the place to pay taxes PBB-P2 is easily accessible by taxpayers and does not require a lot of time to get to the place of tax payment.

\section{METHOD}

This research was conducted in the Karanganyar district of Central Java with consideration based on data on land and building tax revenue for Rural and Urban (PBB-P2) in the Karanganyar district from 2014 to 2018 still far from the target, besides that the $\mathrm{PBB}-\mathrm{P}_{2}$ tax receipt in the Karanganyar district in 2018 has decreased compared to 2017. The people in Karanganyar district are quite varied, consisting of rural and urban communities so that they can provide a more complete picture related to the process of tax collection PBB-P2. This research was conducted from 6 April 2019 until 6 May 2019.

According to (Nawawi, 1983) the population is all objects that can be studied and observed by researchers can consist of living things or eye objects or events, symptoms or values of a test that is processed into a data source of a particular characteristic in the research conducted. This study population is taxpayers $\mathrm{PBB}-\mathrm{P}_{2}$ in Karanganyar district, amounting to 155,799 taxpayers who are in 5 sub-districts in the Karanganyar district, namely Colomadu, Karangpandan, Karanganyar, Tasikmadu, Gondangrejo.

This research is a sampling study where researchers take samples that represent the characteristics of the entire population so that the sample is able to describe the characteristics of a population. The sample is a portion of the entire population taken that is able to represent the characteristics or condition of the population so that the results obtained can be generalized. According to 
(Gulo, 2010) the sample is often referred to as an example that is a part of a population, the sample can explain the picture of a population.

To obtain the sample in this study the Slovin formula was used. The Slovin formula for finding samples from the population is as follows:

$$
\mathrm{n}=\frac{N}{1+N e^{2}}
$$

Where:

n: total sample

$\mathrm{N}$ : total population

e: margin error

From the calculation results, the following values are obtained:

$$
\begin{aligned}
& \mathrm{n}=\frac{155.799}{1+155.799(0,10)^{2}} \\
& \mathrm{n}=\frac{155.799}{1+155.799(0,01)} \\
& \mathrm{n}=\frac{155.799}{1+557,99} \\
& \mathrm{n}=\frac{155.799}{1.558,99}=99,935
\end{aligned}
$$

If rounded up to 100 so the sample that must be taken to interpret 155,799 taxpayers is 100 taxpayers who are in Karanganyar district.

Sampling technique is a technique for taking a number of samples so that the sample can interpret the actual data. In order for the samples obtained to be representative, the sampling must pay attention to the characteristics and distribution of the population. This study uses probability sampling technique, which is a technique to obtain samples, each member of the population has the same opportunity to become a sample, in probability sampling there are various sampling techniques, the researcher uses proportional sampling area. According to (Zuriah, 2007) states that the sample area is a sampling technique that takes into account the sub-population based on the area of population distribution that is the place of research, which is the basis of the amount of each sub-sample is the ratio of the size of the population in each region that is the place of research . In this study, samples were taken in 5 sub-districts in Karanganyar district, namely Colomadu, Karangpandan, Karanganyar, Tasikmadu, Gongangrejo districts, with consideration that in the 5 districts the percentage of realization of $\mathrm{PBB}_{2} \mathrm{P}_{2}$ tax revenue was the lowest among the other districts. Calculation of the number of samples is as follows:

Table 3. Area Sample Calculation

\begin{tabular}{lll}
\hline sub-district & $\begin{array}{l}\text { Sampling area } \\
\text { calculation }\end{array}$ & $\begin{array}{l}\text { Number of } \\
\text { Samples }\end{array}$ \\
\hline Colomadu & $\frac{100}{155.799} \times 31.305=20$ \\
& 20,09 \\
Karangpandan & $\frac{100}{155.799} \times 21.954=14$ \\
& $\begin{array}{l}14,09 \\
\text { Karanganyar }\end{array}$ & $\frac{100}{155.799} \times 33.941=22$ \\
& 21,78 \\
Tasikmadu & $\frac{100}{155.799} \times 26.362=17$ \\
& 16,92 \\
Gondangrejo & $\frac{100}{155.799} \times 42.237=27$ \\
Total & 27,10 \\
\hline
\end{tabular}

Source: DPPKAD Karanganyar district, data processed

Validity is a measure to measure the accuracy or appropriateness or accuracy of the instruments used by researchers to measure an event or phenomenon to be tested (Arifin, 2012). According to (Arikunto, 2010) The 
validity test is used to determine whether a measuring instrument has a density in measurement or to know whether a measuring instrument is really capable of measuring what will be measured.

This instrument test was carried out at the initial stage of distributing questionnaires,
30 respondents were taken from taxpayers in Colomadu sub-district and Karangpandan subdistricts were taken 30 respondents. From the test results using the SPSS 17 program, the following results are obtained:

\section{Taxpayer Compliance Variable}

Table 4. Validity of Taxpayer Compliance Variable

\begin{tabular}{clccc}
\hline No & \multicolumn{1}{c}{ Item } & R-count & R-table & Information \\
\hline 1 & Punctuality & 0,637 & 0,3061 & Valid \\
2 & Understanding & 0,596 & 0,3061 & Valid \\
3 & Compliance with regulations & 0,589 & 0,3061 & Valid \\
4 & Reporting & 0,453 & 0,3061 & Valid \\
5 & Honesty & 0,873 & 0,3061 & Valid \\
6 & Seriousness & 0,715 & 0,3061 & Valid \\
7 & Regularity & 0,747 & 0,3061 & Valid \\
8 & Speed & 0,722 & 0,3061 & Valid \\
\hline
\end{tabular}

Source: Primary data processed, 2019

The results of testing the validity of taxpayer compliance variables in table 4 show that the whole item of items can be said to be valid because the value of $r$-count is greater than the value of r-table, so the conclusion that questions on the taxpayer compliance variable is feasible to be used in this study.

\section{Taxpayer Awareness Variables}

Table 5. Validity of Awareness Variables

\begin{tabular}{lllll}
\hline No & Item & R-count & R-table & Information \\
\hline 1 & Knowledge & 0,706 & 0,3061 & Valid \\
2 & Awareness & 0,744 & 0,3061 & Valid \\
3 & Knowledge of tax functions & 0,750 & 0,3061 & Valid \\
4 & Suitability to pay & 0,377 & 0,3061 & Valid \\
5 & Understand obligations & 0,746 & 0,3061 & Valid \\
\hline
\end{tabular}

Source: Primary data processed, 2019

The results of testing the validity of the that the whole item of items can be said taxpayer awareness variable in table 5 show to be valid because the value of $\mathrm{r}$-count is 
greater than the value of r-table, so it is concluded that the question on the accessibility variable is feasible to be used in this study.

\section{Accessibility Variables}

The results of testing the validity of the accessibility variables in table 6 show that the whole item of items can be said to be valid because the value of $r$-count is greater than the value of r-table, so it is concluded that the question on accessibility variables is feasible to be used in this study.

Table 6. Validity of Accessibility

\begin{tabular}{clccc}
\hline No & \multicolumn{1}{c}{ Item } & R-count & R-table & Information \\
\hline 1 & Convenience & 0,640 & 0,3061 & Valid \\
2 & Infrastructure & 0,725 & 0,3061 & Valid \\
3 & Distance & 0,533 & 0,3061 & Valid \\
4 & Facilities \& infrastructure for disability & 0,799 & 0,3061 & Valid \\
5 & Barriers & 0,633 & 0,3061 & Valid \\
\hline
\end{tabular}

Source: Primary data processed, 2019

\section{Tax Service Variables}

The results of testing the validity of tax service variables in table 7 show that all of the item items can be said to be valid because the value of $r$-count is greater than the value of $r$ table, so it is concluded that questions on tax service variables are feasible to be used in this study.

Table 7. Validity of Tax Services

\begin{tabular}{lllll}
\hline No & Item & R-count & R-table & Information \\
\hline $\mathbf{1}$ & Clarity & 0,540 & 0,3061 & Valid \\
$\mathbf{2}$ & Effectiveness & 0,827 & 0,3061 & Valid \\
3 & Service time & 0,494 & 0,3061 & Valid \\
4 & Speed & 0,618 & 0,3061 & Valid \\
5 & Service fee & 0,680 & 0,3061 & Valid \\
6 & Infrastructure & 0,593 & 0,3061 & Valid \\
7 & Accuracy & 0,576 & 0,3061 & Valid \\
8 & Courtesy service personnel & 0,710 & 0,3061 & Valid \\
9 & Responses to complaints & 0,525 & 0,3061 & Valid \\
\hline
\end{tabular}

Source: Primary data processed, 2019

\section{Variable Tax Sanctions}

The results of testing the validity of the tax sanction variable in table 8 show that the whole item of items can be said to be valid because the value of $\mathrm{r}$-count is greater than the r-table value, so the conclusion that questions on the tax sanction variable is feasible to be used in this study. 
According to (Sumardi, 2004) in research is an appropriate measurement reliability testing is a series of tests that can be tool to measure or analyze an event or used to find out how big a measurement results with the tools used are able to be trusted. Reliability test can be said as a measuring tool to assess whether the tool used phenomenon. The reliability testing of the instrument used in this study was Cronbach's Alpha because the instruments in this study were questionnaires.

Table 8. Validity of Tax Sanctions

\begin{tabular}{lllll}
\hline No & Item & R-count & R-table & Information \\
\hline $\mathbf{1}$ & Criminal sanctions & 0,749 & 0,3061 & Valid \\
$\mathbf{2}$ & Admission sanctions & 0,757 & 0,3061 & Valid \\
3 & Justice & 0,577 & 0,3061 & Valid \\
4 & Understanding of sanctions & 0,680 & 0,3061 & Valid \\
\hline
\end{tabular}

Source: Primary data processed, 2019

Based on the results of the Alpha Cronbach reliability test with the SPSS 17 program with 30 respondents obtained the following results in the table 9.

Table 9. Reliability Test

\begin{tabular}{llll}
\hline No & Variable & $\begin{array}{l}\text { Alpha } \\
\text { Cronbach }\end{array}$ & Information \\
\hline $\mathbf{1}$ & $\begin{array}{l}\text { Taxpayer } \\
\text { compliance }\end{array}$ & $\mathbf{0 , 8 1 8}$ & Reliable \\
$\mathbf{2}$ & $\begin{array}{l}\text { Taxpayer } \\
\text { awareness }\end{array}$ & 0,691 & Reliable \\
3 & $\begin{array}{l}\text { Accessibility } \\
4\end{array}$ & $\mathbf{0 , 6 6 3}$ & Reliable \\
& $\begin{array}{l}\text { Taxation } \\
\text { services }\end{array}$ & 0,795 & Reliable \\
5 & Tax sanctions & 0,629 & Reliable \\
\hline
\end{tabular}

Source: Primary data processed, 2019

The reliability test in table 9 shows that all variables used are reliable or appropriate to use, because the value of Alpha Cronbach is more than o.6.

This research is a quantitative research that is research that is measured by numbers. According to (Sugiyono, 2015) quantitative research is research that uses methods that have the idea that all phenomena are based on real or empirical data and are used to test several samples that are able to explain the condition of a population. The data analysis technique used is descriptive statistical analysis of percentages using pie charts. Pie chart or commonly called a pie chart is a form of statistical graph that forms a circle that is divided into several slices and the extent depends on the numerical proportions or the quantity of data held. A pie chart is a simple chart that is useful for describing parts of an entire data, a pie chart is a chart based on numerical data that allows researchers to show proportions in percentages. Pie chart diagrams are very useful for describing the contribution of one thing to another. Pie charts are used to compare between sections against totals. Pie charts are usually in the form of percentages because the values are the parts that are summed together, so that it can be seen that the biggest or the smallest contribution in forming value. Pie charts are used for small comparisons because too many cannot read 
the chart properly. One circle on a pie chart shows a whole or one hundred percent while a half circle shows a proportion of half of the total. Pie chart does not show data directly, there are several advantages of a pie chart, namely: save space because the pie chart does not require a lot of places, can directly show the comparison of each data size, besides that the pie chart also has some shortcomings including: not showing data size or frequency of each data.

This study uses primary data which is data obtained in research taken directly from the informant. Primary data in the study were obtained by taking directly from taxpayers PBB-P2 in Karanganyar district.

\section{RESULTS AND DISCUSSION}

\section{Taxpayer Awareness}

Taxpayer awareness of taxation is a sense that arises from within the taxpayer his obligation to pay taxes willingly without any element of coercion. The taxpayer is said to have awareness if: knowing the existence of laws and taxation provisions, knowing the tax function for state financing. Based on the results of research conducted by researchers, the level of awareness of taxpayers in Karanganyar Regency is obtained as follows:

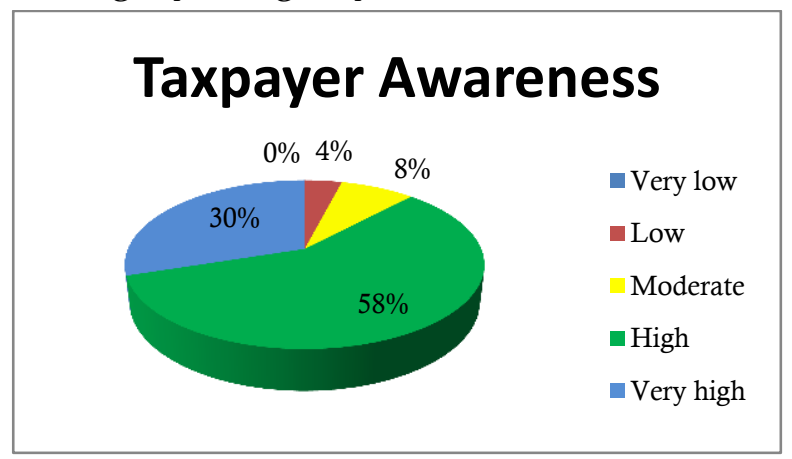

Figure 1. Taxpayer awareness chart pie chart Source: Primary data processed, 2019
Based on the data obtained it can be concluded that awareness of taxpayers in Karanganyar district can be said to be high because according to the data 80\% more respondents have high awareness or even very high, with high taxpayer awareness being able to increase taxpayer compliance to pay taxes especially UN tax $\mathrm{P}_{2}$ which will result in increasing regional income, especially from the tax sector. Awareness of high taxpayers is inseparable from the role of the Karanganyar district government who made efforts to increase taxpayer awareness in the Karanganyar district. One of the efforts made by the Karanganyar district government to increase taxpayer awareness is to install billboards at several red light points and a crossroads that contain an invitation or appeal to pay $\mathrm{PBB}-\mathrm{P}_{2}$ taxes on time.

\section{Timeliness in Paying Taxes}

Timeliness in paying taxes is a condition where taxpayers who always obey pay taxes and pay $\mathrm{PBB}-\mathrm{P}_{2}$ taxes before the specified maturity. Based on research conducted by researchers, the level of punctuality of paying PBB-P2 tax in Karanganyar Regency is obtained as follows:

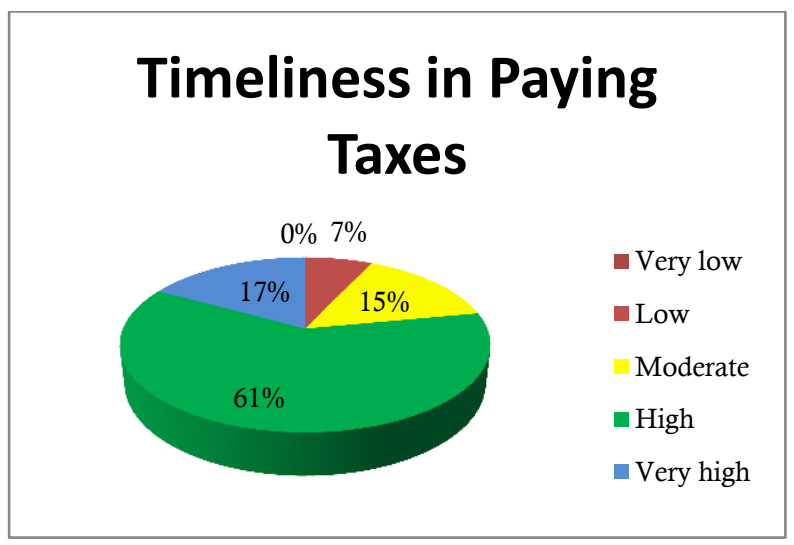

Figure 2. Pie chart for timeliness to pay Source: Primary data processed, 2019 
Based on these data it can be concluded that the level of timeliness of paying taxes by taxpayers in Karanganyar district is included in the high category because as many as $70 \%$ more taxpayers have a high level of punctuality paying taxes even very high. The level of accuracy of time to pay high taxes can increase regional income from the tax sector, especially PBB-P2 tax in Karanganyar district, which will be used to finance regional expenditure. The high level of timeliness of paying PBB-P2 taxes in Karanganyar district cannot be separated from the role of the Karanganyar district government which issued a policy to improve the timeliness of paying $\mathrm{PBB}_{2} \mathrm{P}_{2}$ taxes in Karanganyar district. One of the efforts made by the local government to improve the timeliness of paying PBB-P2 tax is to conduct a $\mathrm{PBB}-\mathrm{P}_{2}$ lottery draw in the sub-district which pays the PBB-P2 arrears quickly and before maturity. The draw was conducted to attract taxpayers to pay $\mathrm{PBB}-\mathrm{P} 2$ tax in Karanganyar district to pay $\mathrm{PBB}-\mathrm{P} 2$ tax on time.

\section{Facilities and Infrastructure for Disabilities}

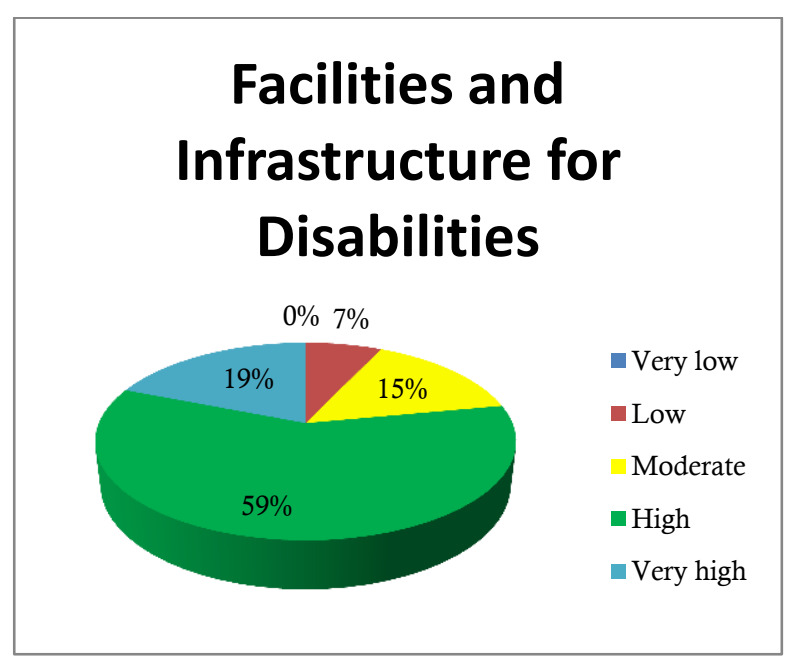

Figure 3. Pie chart for facilities and infrastructure for disabilities Source: Primary data processed, 2019
Disability is the inability or lack of both physical and mental so there are limitations to do something. In Indonesia, public facilities and infrastructure are less friendly to persons with disabilities, whereas persons with disabilities also have the same right to use public facilities and infrastructure provided by the government. Based on the results of research conducted by researchers obtained data as follows:

Based on Figure 3 pie chart diagram of facilities and infrastructure for disability can be seen from 100 respondents studied as many as $59 \%$ stated that facilities and infrastructure for disability are high, 19\% stated facilities and infrastructure for disability are very high, as many as $15 \%$ stated facilities and infrastructure for moderate disability while $7 \%$ stated that facilities and infrastructure for disability were low.

Based on the data obtained it can be concluded that the facilities and infrastructure of paying $\mathrm{PBB}_{2} \mathrm{P}_{2}$ tax for persons with disabilities is quite high because as many as $70 \%$ of respondents answered that the facilities and infrastructure for high disability are even very high. The Karanganyar district government certainly plays a very important role in providing facilities and infrastructure for people with disabilities. Based on research conducted by researchers, there are indeed a number of places that provide friendly facilities and infrastructure for people with disabilities such as the DPPKAD office that provides special stairs for persons with disabilities and in some districts there are similar facilities and infrastructure, but unfortunately friendly facilities and infrastructure for persons with disabilities, they are not provided at the kelurahan office 
only at the sub-district level, even though those entitled to use public facilities for disability are not limited to the sub-district only. Another convenience that is obtained in paying $\mathrm{PBB}-\mathrm{P} 2$ tax in Karanganyar district is that taxpayers can leave it to the environmental coordinator, parrots and village officials who have been appointed to make tax payments for $\mathrm{PBB}-\mathrm{P}_{2}$ so that persons with disabilities do not need to come to the place of PBB-P2 to make payment of tax is sufficient to be entrusted.

\section{Ease of Paying Taxes}

Ease of paying taxes is a condition where taxpayers who will pay taxes do not experience difficulties. According to the DGT website the key to tax compliance is ease of paying taxes. Ease of paying taxes can be realized, among others, by always improving the payment system electronically, combining several types of taxes or even removing irrelevant types of taxes and simplifying the taxpayer reporting process. Based on the results of research that has been done, the following data are obtained:

\section{Ease of Paying Taxes}

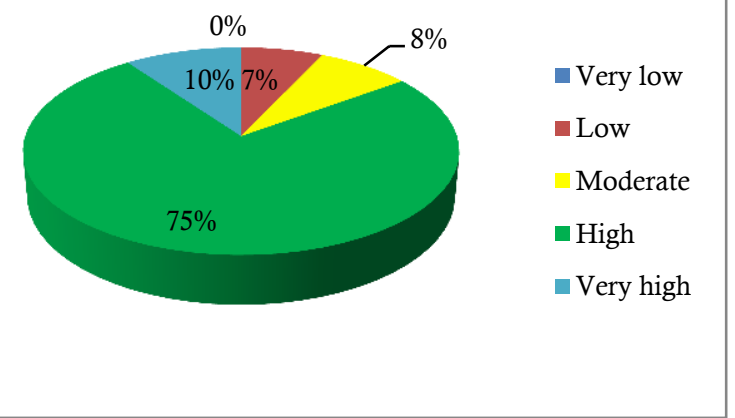

Figure 4. Pie chart for ease of paying taxes Source: Primary data processed, 2019
Based on Figure 4 pie chart diagram the ease of paying taxes can be seen from 100 respondents as many as $75 \%$ consider the ease of paying high taxes, as many as $10 \%$ consider the ease of paying taxes very high, as many as $8 \%$ consider the ease of paying moderate taxes while as many as $7 \%$ consider the ease of paying low taxes. Based on the data obtained it can be concluded that the ease of paying $\mathrm{PBB}-\mathrm{P}_{2}$ tax in Karanganyar district is very high because as many as $85 \%$ of 100 respondents consider that the ease of paying $\mathrm{PBB}_{2} \mathrm{P}_{2}$ tax in Karanganyar district is even very high. The level of ease of paying taxes is high because the government is always making efforts to increase the ease of paying taxes to increase state revenue. One of the efforts made by the Karanganyar district government is to implement e-filling and e-billing. E-filling is a way of electronically delivering SPT which is done online and in real time. E-billing is an electronic tax payment method using a billing code, but the policy is not accompanied by the socialization of how to use it, this can be reflected in the obstacles faced by taxpayers, some of whom state that there is no socialization of tax payment methods $\mathrm{PBB}-\mathrm{P}_{2}$, so many taxpayers choose to make PBB-P2 tax payments manually through bank tellers.

\section{Taxpayer Compliance}

Taxpayer compliance is the fulfillment of tax obligations carried out by taxpayers in the context of contributing to the development of a country. Compliance climate is a condition where taxpayers understand or try to fulfill all the provisions of tax legislation, fill tax forms completely and clearly, calculate the amount of tax owed correctly, pay tax owed on time. 
Based on the research that has been done, the UN-P2 taxpayer compliance data in Karanganyar Regency is as follows:

\section{Taxpayer Compliance}

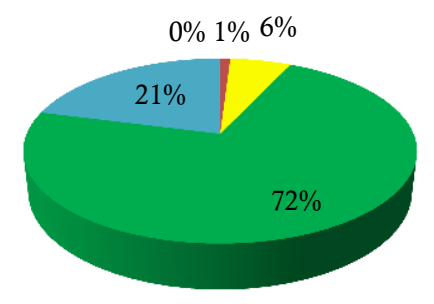

$$
\begin{aligned}
& \text { Very low } \\
& \text { Low } \\
& \text { Moderate } \\
& \text { High } \\
& - \text { Very high }
\end{aligned}
$$

Figure 5. Taxpayer compliance chart pie chart Source: Primary data processed, 2019

Based on Figure 5 pie chart diagram tax compliance can be seen from 100 respondents studied as many as $72 \%$ have high tax compliance, $21 \%$ of respondents have very high tax compliance, $6 \%$ have moderate tax compliance while $1 \%$ of taxpayers have tax compliance low. Based on the data obtained it can be concluded that taxpayer compliance in paying PBB-P2 tax in Karanganyar Regency is classified as very high because of as many as 90\% more than 100 respondents have high tax compliance and even very high. Taxpayer compliance is influenced by several factors, in Karanganyar district itself factors that can encourage compliance with high taxpayers are by increasing taxpayer awareness, increasing ease of paying taxes, improving facilities and infrastructure as well as providing rewards to taxpayers who are obedient to paying taxes, where several factors This has been carried out in Karanganyar Regency including installing billboards and banners in public places to increase taxpayer awareness, create e-filling and e-billing systems to make it easier to pay PBB-P2 taxes, improve facilities and infrastructure for paying taxes. High taxpayer compliance is highly expected by the Karanganyar district government because with a high level of compliance paying PBB-P2 tax can increase regional income used to finance local government expenditure.

\section{Clarity of Service Procedures}

Clarity of tax service procedures will make taxpayers understand their rights and obligations in paying tax $\mathrm{PBB}-\mathrm{P}_{2}$. Taxpayers who understand their rights and obligations in paying $\mathrm{PBB}-\mathrm{P}_{2}$ tax can certainly increase their level of compliance in paying $\mathrm{PBB}_{2} \mathrm{P}_{2}$ tax. Based on the results of research conducted by researchers, the following results are obtained:

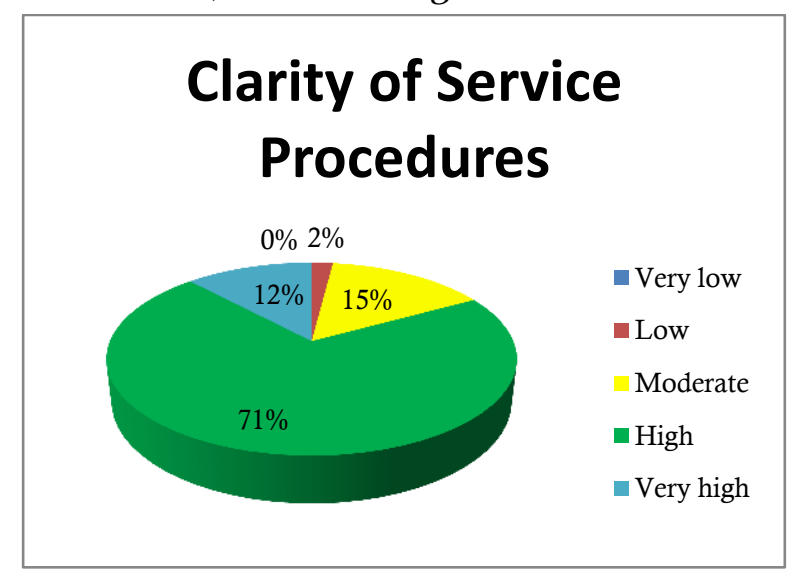

Figure 6. Pie chart for clarity of service procedures

Source: Primary data processed, 2019

Based on picture 6 the clarity of tax service procedures can be seen that out of 100 respondents as many as $71 \%$ consider that the clarity of tax service procedures is high, as many as $12 \%$ consider that the clarity of tax service procedures is very high, as much as $15 \%$ assume that the clarity of tax service procedures is moderate while as much as $2 \%$ taxpayers assume that the clarity of tax service procedures is low. Based on the data obtained, it can be concluded that the procedure of PBB$\mathrm{P}_{2}$ tax payment service in Karanganyar district 
is high because $83 \%$ of the total respondents consider the procedure of $\mathrm{PBB}-\mathrm{P}_{2}$ taxation service in Karanganyar regency even high. The procedure for taxation services in Karanganyar district itself is not so complicated that taxpayers simply come to the UN-P2 tax payment site that has been provided or to the Central Java bank through a teller by bringing SPPT and then paying according to the stated amount. Tax service procedures in Karanganyar Regency are also posted in the glass of the tax payment service section to provide an overview of taxpayers who pay PBB$\mathrm{P}_{2}$ tax on their rights and obligations in paying taxes and obtaining good services, but unfortunately this tax service procedure is also not attached to the village office and the Central Java bank which is used for the payment of tax PBB-P2.

\section{Competency of Tax Service Officers}

The competency of tax service officers is needed to serve tax payment PBB-P2 so that taxpayers who pay taxes feel served and get good service according to (Todaro, 1983) in most developing countries the results of state revenue from taxes are very low this is because tax collection is not carried out with seriously, there is no tax law system that proves the existence of conflict between the tax administration regulators and taxpayers. An efficient tax administration must consist of people whose high integrity is the most important requirement for achieving maximum tax revenue and truly exploring the taxation potential of a country. Based on the results of research conducted by researchers, the following data are obtained:

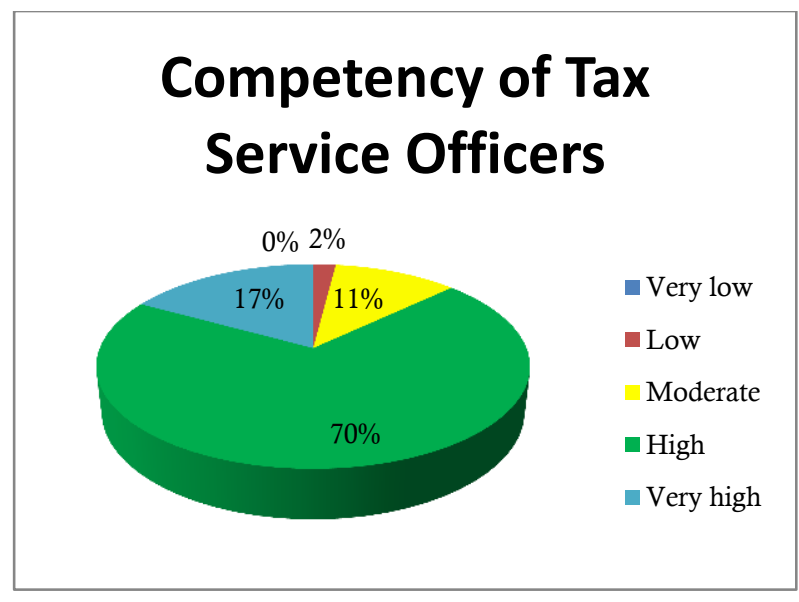

Figure 7. Competency of taxation service officers

Source: Primary data processed, 2019

Based on Figure 7 pie chart diagram of the competence of tax service officers can be seen from 100 respondents as many as $70 \%$ assume that tax service officers are already high, as much as $17 \%$ of respondents consider that the competency of service officers is very high, as much as $11 \%$ of respondents consider the competency of tax service officers to be moderate whereas as many as $2 \%$ of respondents consider the competency of tax service officers to be low. Based on the data obtained, it can be concluded that the competency of taxation service officers is already quite high because as many as $87 \%$ of the total respondents consider that the competency of taxation service officers is already high or even very high. the competence of a good tax service officer will affect local revenue from the tax sector because it can increase taxpayer compliance to pay tax PBB-P2. Tax service officers in Karanganyar regency mostly come from Central Java banks. Based on the results of research conducted by researchers, researchers provide several questions to tax service officers 
(employees of Central Java bank) regarding how the payment mechanism, what systems are used in tax payment PBB-P2, and the tax service officer answers in complete and detailed. The drawbacks of taxation services in Karanganyar district are related to the system used because based on the experience of researchers when conducting research servers used to pay taxes $\mathrm{PBB}-\mathrm{P}_{2}$ often experience errors and can last for more than a week so that server errors will inhibit taxpayers who will make tax payments $\mathrm{PBB}-\mathrm{P}_{2}$, many taxpayers do not pay taxes or return home because the service was closed due to an error server, this would certainly be detrimental to regional income because regional income could be reduced due to taxpayers who pay taxes late due to server errors. So it can be concluded that the competency of Karanganyar regency tax service officers is good but server improvements need to be done to improve taxation services so that they can increase local revenue.

\section{Objection of Applicable Tax Sanctions}

Tax sanctions are needed so that taxpayers who are not compliant or obedient to pay taxes and comply with applicable tax regulations can get penalties and get a deterrent effect. Based on the results of research conducted by researchers, the following data are obtained:

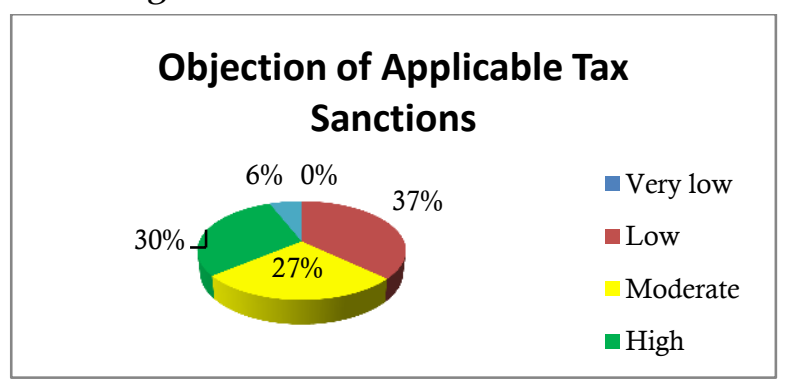

Figure 8. Figure 8 . Pie chart of objections to applicable sanctions

Source: Primary data processed, 2019
Based on the picture 8 objections to the applicable sanctions, then obtained data from 100 respondents as many as $30 \%$ of respondents claimed objections to sanctions that are high, as many as $6 \%$ claimed objections to tax sanctions that apply very high, as much as $27 \%$ of respondents claimed to object to tax sanctions that are moderate while as many as $37 \%$ of respondents said they objected to the tax sanctions that apply low. Based on the data obtained, it can be concluded that the objections of taxpayers to the applicable tax sanctions in Karanganyar district are low because according to the data as much as $37 \%$ or most respondents said that tax sanctions are not too burdensome for them. Tax sanctions are used to regulate taxpayers who do not comply with applicable tax regulations. Tax sanctions in the Karanganyar district in the form of administrative sanctions as much as $2 \%$ of the tax payable for late payment each month while criminal sanctions for taxpayers who do not pay $\mathrm{PBB}-\mathrm{P}_{2}$ tax are criminal. Karanganyar regency regulation has explicitly regulated this matter, if this regulation is implemented and disciplined, taxpayers who do not carry out their obligations will receive punishment and deterrent effect, but in reality based on the results of interviews conducted by researchers on several village officials and based on previous research it is said that tax sanctions both administrative sanctions and criminal sanctions are less enforced in the Karanganyar district, with the non-enforcement of these tax sanctions can make taxpayers not deterred from carrying out tax evasion or being late in paying taxes. This is one of the causes of taxpayers not paying taxes on time and resulting in revenue from the tax sector, 
especially the PBB-P2 tax in Karanganyar district, which has never reached the target for 5 years in a row. Therefore the government needs to make efforts to enforce tax sanctions and supervise taxpayers who carry out tax evasion and who are late in paying $\mathrm{PBB}-\mathrm{P}_{2}$ taxes.

\section{CONCLUSION}

Based on research conducted using pie chart diagram, the following conclusions are obtained: 1) Taxpayer awareness in Karanganyar Regency is high, punctuality in paying taxes in Karanganyar district is high, facilities and infrastructure for disability in paying taxes in Karanganyar Regency are high, tax compliance in the district Karanganyar is high, the clarity of tax service procedures in Karanganyar district is high, the competency of tax service officers in Karanganyar district is high, objections to taxpayers against tax sanctions in Karanganyar are low because according to interviews conducted by researchers and previous research states that tax sanctions are less enforced in the district Karanganyar. Based on the results obtained, the conclusion is that tax sanctions that are not enforced in Karanganyar Regency are the reason for the realization of $\mathrm{PBB}-\mathrm{P}_{2}$ tax revenue in Karanganyar Regency, which has not reached the target for the past 5 years.

Based on the research that has been done and the conclusions obtained, the researcher gives some suggestions as follows: 1) The Karanganyar district government should enforce sanctions that have been made to anyone who disobeyed taxpayers and violate applicable regulations and conduct supervision of disobedient taxpayers pay taxes and do tax evasion.

\section{REFERENCES}

Adisetiawan. (2011). Analysis of the Effect of Financial Performance on Earnings Growth. Journal of the Batanghari Faculty of Economics.Arifin, Z. (2012). Penelitian Pendidikan. Bandung: PT. Remaja Rosdakarya.

Arikunto, S. (2010). A Practical Approach. Jakarta: Rineka Cipta.

Arsyad, L. (1999). Introduction to Regional Economic Planning and Development, First Edition. Yogyakarta: BPFE.

Ayunda, W. P. (2015). The Effect of Tax Sanctions, Taxation Knowledge, Taxpayer Attitudes, and Economic Level Against Taxpayer Compliance in Paying Land and Building Taxes with the Control Variables of Village Officers as Moderating Variables in Pekanbaru City.

Burton, I. d. (2010). Tax law. Jakarta: Salemba Empat.

Faizah, S. (2009). Factors That Affect Taxpayer Compliance in Paying Land and Building Taxes.

Ghozali, I. (2005). Multivariate Analysis Application with SPSS. Semarang: UNDIP.

Ghozali, I. (2013). Multivariate Analysis Application with SPSS. Semarang: UNDIP.

Gujarati, D. N. (2015). Econometrics Basics. Jakarta: Salemba Empat.

Gulo, W. (2010). Research methodology. Jakarta: Grasindo.

Juwanti, F. R. (2017). The Influence of Tax Knowledge, Taxpayer Awareness, Social Norms, Trust in Government and Tax Sanctions Against Taxpayer Compliance in Paying Land and Building Taxes.

Kamaludin, R. (1983). Some Aspects of National and Regional Development. East Jakarta: Ghalia Indonesia.

Ministerial decree PAN Number 63/KEP/M.PAN/7/2003 About Public Service Standards.

Ministerial decree PAN No 25 Year 2004

Laksito. (2014). Factors affecting taxpayer compliance with paying land and building taxes.

Larmanto. (2008). Implementation of Land and Building Tax (PBB) Tax Collection Policy in Karanganyar Regency. Thesis. 
Lungan, R. (2006). Application of Statistics and Calculate Opportunities. Yogyakarta: Graha Science.

Mardiasmo. (2018). Taxation Latest Edition 2018. Yogyakarta: ANDI Yogyakarta.

Moh.Zain. (2004). Tax Management. Jakarta: Salemba Empat.

Moleong, L. J. (2005). Qualitative Research Methodology. Bandung: Teen Rosdakarya.

Muhammad, i. (2009). Social Sciences Research Methods. Yogyakarta: Erlangga.

Munawir, S. (1990). Taxation for Senior High Schools. Yogyakarta: BPFE-Yogyakarta.

Nawawi, H. H. (1983). Descriptive research method. Yogyakarta: Gajah Mada University Press.

Nayoan, N. (2016). Effects of Understanding Taxpayers, Ease of Paying Taxes, and Changes in PP No. 46 of 2013 Against UMKM Taxpayer Compliance in Pekanbaru City.

Oktiyani, R. (2016). Tax Awareness and Community Perceptions About the Tax Obligation to Pay UN Taxes in Ngasem Village, Colomadu District, Karanganyar Regency.

Pasolong, H. (2013). Bureaucratic Leadership. Bandung: CV. Alfabeta.

Regional Regulation of Karanganyar Regency No 3 Year 2012 About the Rural and Urban Land and Building Tax.

Regional Regulation Number 3 Year 2013.

Regional Regulation Number 13 Year 2012.

Prasetyawan, A. W. (2014). Exploring the potential of land and building tax in rural and urban areas to increase original income of Karanganyar Regency.

Putra, I. M. (2017). Taxation Edition: Tax Amnesty. Yogyakarta: Quandrant.

Rahayu, S. K. (2010). Indonesian Taxation: Formal Concepts and Aspects. Yogyakarta: Graha Science.

Rina Oktiyani, S. L. (2016). Tax Awareness and Public Perceptions About Tax Obligations Against
Compliance in Paying the United Nations in Ngasem Village, Colomadu District, Karanganyar Regency in 2016.

Soemitro. (2001). Property tax. Jakarta: Directorate of the UN and BPHTB.

Soemitro, R. (1974). Tax and Development. Bandung: PT. Eresco.

Soemtiro, R. (1989). Tax and Development. Bandung: PT. Eresco.

Sri, V. d. (2006). Indonesian taxation. Jakarta: Salemba Empat.

Suandy, E. (2002). Tax Law Issue 2. Jakarta: Salemba Empat.

Sudjana. (2002). Statistical Method. Bandung: Tarsito.

Sugiyono. (2015). Quantitative, Qualitative, and R\&D Research Methods. Bandung: ALFABETA.

Sujarweni, V. W. (2014). SPSS for Research. Yogyakarta: New Library.

Sumardi, S. (2004). Research methodology. Jakarta: PT. Raja Grafindo Persada.

Suryanita. (2015). Analysis of Factors Affecting the Compliance Level of Taxable Entrepreneurs at the Temanggung Tax Service Office.

Todaro, M. P. (1983). Economic Development in Third World Countries. East Jakarta: Balai Aksara.

Constitution Number 28 Year 2009 Regarding Local Taxes.

Constitution Number 33 Year 2004.

Constitution Number 5 Year 1974 About the Principles of Regional Government.

Constitution Number 28 Year 2009 About Regional Taxes and Regional Levies.

Constitution RI Nomor 28 Year 2007 About General Provisions and Tax Procedures.

Constitution Number 19 Year 2000.

Zuriah, N. (2007). Social and educational research methodology. Jakarta: PT. Mighty Earth. 